\title{
TRAPPC10 Gene
}

National Cancer Institute

\section{Source}

National Cancer Institute. TRAPPC10 Gene. NCI Thesaurus. Code C75424.

This gene may play a role in protein transport. 